\title{
Effect of acute methyl methacrylate vapor inhalation on smokers' and non-smokers' respiratory function in a sample of male dentistry students
}

\section{Wpływ wdychania znacznych ilości oparów metakrylanu metylu na funkcje oddechowe osób palących i niepalących - na przykładzie studentów stomatologii płci męskiej}

\author{
Malath Azeez Al-Saadi ${ }^{1, A-F}$, Anas Al-Yasiry',A,B,E,F, Zainab Al-Jammalii, ${ }^{2, B, E, F}$, Aoss Moez ${ }^{1, B, F}$ \\ ${ }^{1}$ Department of Basic Science, Faculty of Dentistry, University of Babylon, Hilla, Iraq \\ ${ }^{2}$ Department of Prosthodontics, Faculty of Dentistry, University of Babylon, Hilla, Iraq \\ A - research concept and design; $\mathrm{B}$ - collection and/or assembly of data; $\mathrm{C}$ - data analysis and interpretation; \\ $\mathrm{D}$ - writing the article; $\mathrm{E}$ - critical revision of the article; $\mathrm{F}$ - final approval of the article
}

Address for correspondence

Malath Azeez Al-Saadi

E-mail: malathazeez1122@gmail.com

Funding sources

None declared

Conflict of interest

None declared

Received on August 6, 2018

Reviewed on November 4, 2018

Accepted on December 1, 2018

Published online on March 29, 2019

Cite as

Al-Saadi MA, Al-Yasiry A, Al-Jammali Z, Moez A. Effect of acute methyl methacrylate vapor inhalation on smokers' and non-smokers' respiratory function in a sample of dentistry male students. Dent Med Probl. 2019;56(1):75-80. doi:10.17219/dmp/100444

DOI

$10.17219 / \mathrm{dmp} / 100444$

Copyright

๑ 2019 by Wroclaw Medical University

This is an article distributed under the terms of the

Creative Commons Attribution Non-Commercial License

(http://creativecommons.org/licenses/by-nc-nd/4.0/)

\begin{abstract}
Background. Methyl methacrylate (MMA) is one of the widely used organic monomers in dentistry. It may cause multiple adverse reactions, ranging from allergic reaction to systemic toxicity. Dentistry students are exposed to MMA in an acute manner; however, the concentration of its vapor cannot be estimated well.

Objectives. The aim of this study was to evaluate the effect of acute MMA vapor inhalation on the pulmonary function of dental students, both smokers and non-smokers.
\end{abstract}

Material and methods. Thirty-eight male dental students were divided into 2 groups (group 1 - smokers and group 2 - non-smokers). The lung function parameters of the students were tested with a spirometer during their ordinary training work in a prosthodontics laboratory, before contact with MMA and immediately after it. The lung function test was performed using a standard protocol. The students were asked not to use any perfume or aromatic overlaps for a period of $24 \mathrm{~h}$ before starting the tests.

Results. The researchers noted a statistically significant decrease $(p \leq 0.05)$ in forced vital capacity (FVC), forced expiratory volume in $1 \mathrm{~s}$ (FEV1), peak expiratory flow (PEF), forced expiratory flow at 25-75\% of the pulmonary volume (FEF25-75), and forced expiratory flow at 25\% (FEF25) and 50\% (FEF50) of the pulmonary volume in smokers and non-smokers by comparing the pre- and post-work tests.

Conclusions. Acute inhalation of MMA vapor induced a moderate restriction of pulmonary function in dental students, both smokers and non-smokers, during their routine prosthodontics laboratory training work. No differences in the results of the pulmonary function tests between smokers and non-smokers were observed.

Key words: spirometer, pulmonary function, smokers, methyl methacrylate

Słowa kluczowe: spirometr, funkcjonowanie płuc, osoby palące, metakrylan metylu 


\section{Introduction}

Dental practitioners and dentists are frequently in contact with multiple types of polymers, especially methyl methacrylate (MMA). ${ }^{1}$ Metyl methacrylate is a clear organic dissolvent, which is used in the preparation of complete or partial dentures and other dental composite restorations, as well as in the preparation of orthopedic cement. The vapor of MMA has been known for its effect on health, especially when used chronically in poorly ventilated areas. ${ }^{2}$ The major documented health problems associated with the exposure to MMA include irritation of skin, eyes and the mucus membrane of both the upper and lower respiratory tract. ${ }^{3,4}$ Multiple measures have been taken to decrease contact with MMA, such as gloves, masks and proper ventilation, but this is still not enough to limit the exposure to the widely used MMA and stop the inhalation. ${ }^{5}$ For decades, many studies have attempted to determine the degree of toxicity of MMA, including animal and human studies. These studies clarified the mechanism of MMA toxicity, which can be attributed to a local interaction between MMA and the mucus membrane of the respiratory system. The local interaction consists in the neural stimulation, appearing in the form of coughing, mucus secretion and accumulation, which leads to the narrowing of the airways and bronchospasm, in addition to lacrimation, resulting from the cholinergic stimulation. Although it is reversible, upon continuous exposure, cellular damage and necrosis may happen. ${ }^{6}$

Dentistry students are exposed to MMA in an acute manner. As the concentration of its vapor cannot be estimated well, they are secondary users with a great chance of hypersensitivity development.7,8 Vaporization takes place upon mixing a monomer with acrylic powder, leading to the irritation of lung and respiratory epithelia. Since MMA is lipophilic, it has the ability to penetrate the epithelial cell wall, causing lipid peroxidation, lactate dehydrogenase leakage, generation of free radicals, and accumulation of inflammatory cells, which leads to capillary hyperemia, edema, loss of respiratory epithelial cilia, and necrotic cell death, depending on the exposure concentration as explained by previous studies on an animal model and the alveolar cell line. ${ }^{9-11}$

Smokers already have an irritated respiratory epithelium as a result of the direct effect of cigarette smoke on the endothelial integrity. The consequences are increased vascular contraction of small blood vessels and decreased pulmonary vascular lumen capacity due to the reduction of endothelial nitric oxide-dependent vasodilation, which leads to emphysema with pulmonary hypertension, causing deleterious changes similar to those typical of chronic obstructive pulmonary disease. ${ }^{12}$ Changes in lung function among smokers vary according to age, sex and the number of cigarettes smoked per day. ${ }^{13}$

The lung function tests represent a good and efficient method to predict the risk of obstructive pulmonary disease and cardiovascular problems due to the restricted air flow, caused by cigarette smoke and other irritating inhalants. ${ }^{14,15}$

The aim of this study was to evaluate the acute effect of MMA on the lung function of dental students, including male smokers and non-smokers.

\section{Material and methods}

The study was conducted in the Faculty of Dentistry, University of Babylon, Hilla, Iraq (from September to December, 2017). This is a comparative, non-randomized study that included student volunteers. The applied procedures were in accordance with the ethical standards of the Dentistry College scientific committee and with the Helsinki Declaration of 1975, as revised in 2000. Ethical committee approval number: 109-2017.

\section{Volunteers}

A total of 38 male dentistry students aged 20-22 years were divided into 2 groups (Fig. 1): group 1 included 19 smokers with a history of smoking about 20 cigarettes a day for more than 2 years; group 2 included 19 nonsmokers, all of whom were healthy, with good general and respiratory conditions, according to the survey performed by the researchers.

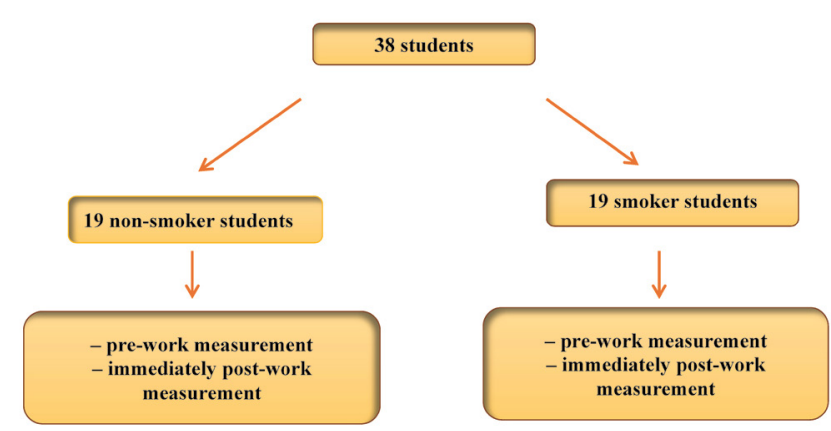

Fig. 1. Study design

\section{Exclusion criteria}

Before starting the tests, the volunteers were interviewed. Students with systemic respiratory disease or diagnosed with respiratory allergic reaction to chemicals were excluded from the study. The students were asked not to use any perfume or aromatic overlaps for a period of $24 \mathrm{~h}$.

\section{Pulmonary function test (procedures)}

At the beginning, a complete history of the student, especially in the case of smokers (duration of smoking), was obtained. Then, a stadiometer was used to record 
height and weight without shoes, by means of standard techniques (in the Frankfort horizontal plane, the patient standing in the upright position). ${ }^{16,17}$ Information regarding the students, such as age, race/ethnicity and other data was entered into the software program of the spirometer (Spirobank II ${ }^{\circledR}$; MIR, Rome, Italy). ${ }^{16,18}$ A spirometer is an apparatus that measures the air which is breathed into the lungs through inspiration and out of the lungs during expiration (Fig. 2). ${ }^{18}$

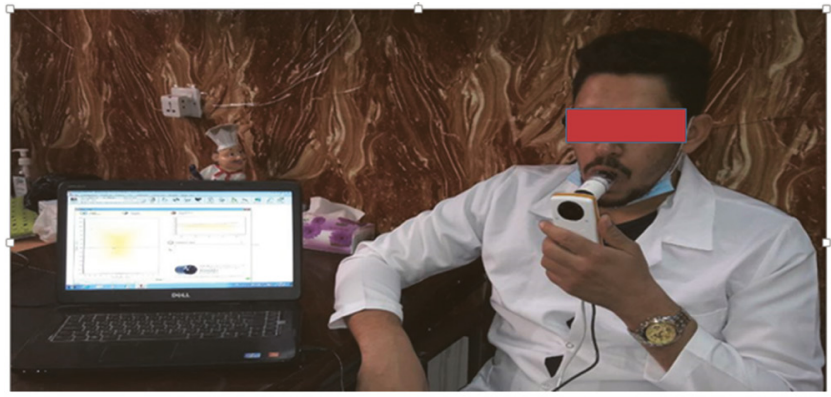

Fig. 2. Spirometer handling and work (The photograph was taken with the approval of the scientific committee of the Department of Prosthodontics, Faculty of Dentistry, University of Babylon, Hilla, Iraq, and with the consent of the student.)

Before the pre-work measurement, the method was thoroughly explained to the study volunteers. Then, a nose clip was applied to plug the nasal pathway. After that, the participants were asked to take a deep breath and put a mouthpiece in their mouth. The mouthpiece was fixed inside the mouth by the teeth and lips to achieve complete sealing, and also to make sure the air did not excite during maximal forced expiration, which takes at least $6 \mathrm{~s}$.

The test measurements were repeated 3 times and the greatest of the records were taken into consideration, according to the spirometer protocol. The data was presented as a percentage of the value predicted for age, height and weight, based on the spirometer table.

The immediate post-work measurement was performed using latex gloves, protective glasses, a mask, and a laboratory coat. The cold-cured acrylic (Vertex ${ }^{\circledR}$; Vertex-Dental B.V., Soesterberg, the Netherlands) (30 mL of powder and $10 \mathrm{~mL}$ of monomer) was mixed by the participants to construct a custom tray or record base in a well-ventilated laboratory $(9 \times 6 \mathrm{~m})$; the time of exposure to the monomer was approx. $30 \mathrm{~min}$. The test was taken immediately after the students' exposure to the monomer in the laboratory, in the same way as previously described.

\section{Parameters tested}

The lung function test uses a standard protocol with a spirometer to measure: forced vital capacity (FVC), forced expiratory volume in $1 \mathrm{~s}$ (FEV1), the ratio of forced expiratory volume in $1 \mathrm{~s} /$ forced vital capacity (FEV1/FVC), peak expiratory flow (PEF), forced expiratory flow at 25-75\% of the pulmonary volume (FEF25-75), and forced expiratory flow at 25\% (FEF25) and 50\% (FEF50) of the pulmonary volume, where $25 \%, 50 \%$ and $75 \%$ reflect the bronchial diameter from bigger to smaller, respectively. ${ }^{16,17}$

\section{Statistics}

Statistical data was presented as mean \pm standard deviation $(S D)$ and percentage. The analysis of data was performed with the IBM SPSS Statistics software, v. 21.0 (IBM Corp., Armonk, USA), using the independent samples $t$-test and one-way analysis of variance (ANOVA) with a $p$-value $\leq 0.05$ considered statistically significant.

\section{Results}

The current study found a statistically significant decrease in FVC and FEV1 $(p \leq 0.05)$ in both smokers and non-smokers, comparing the pre- and post-work tests (Fig. 3,4), while the FEV1/FVC percentage showed a nonsignificant change while comparing the pre- and postwork tests in each group and the results of the groups together.

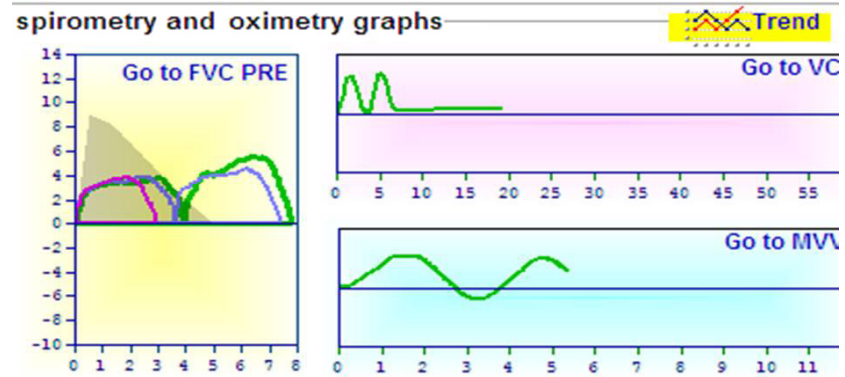

Fig. 3. Illustration of the results of one of the spirometer tests

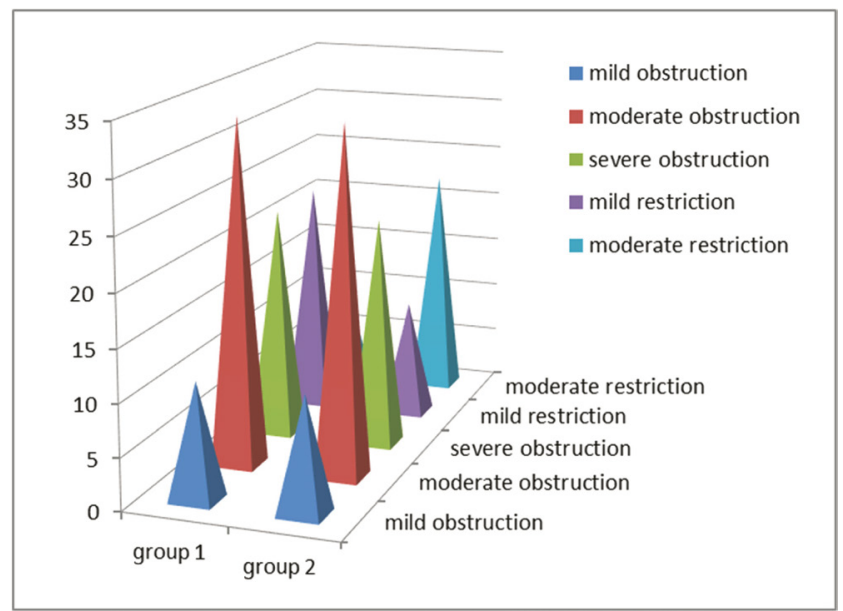

Fig. 4. Spirometer diagnostic diagram referring to the pre- and immediately post-work tests 
On the other hand, PEF, FEF25-75 and FEF25 showed a statistically significant reduction $(p \leq 0.05)$ while comparing the pre- and post-results in group 1, and PEF, FEF25-75, FEF25, and FEF50 in group 2 showed a significant decrease $(p \leq 0.05)$ (Table 1$)$. No significant differences were observed among the groups when all test results were compared $(p>0.05)$ (Table 2).

\section{Discussion}

Normal respiratory function is of great value for a normal healthy life without morbidity. The work environment is filled with different types of pollutants, but the exact effect of these pollutants depends on their concentration, the exposure time and the circumstances of exposure. Methyl methacrylate accounts for the most widely known toxicant vapor, especially in the dentistry field. ${ }^{19}$

Dental students are exposed to MMA vapor during their ordinary work when constructing special trays and record bases of complete and partial dentures, as required in their studies. Previous research showed that MMA vapor induced acute pulmonary obstruction, depending on certain exposure time and concentration. ${ }^{20}$ In the current study, our aim was to evaluate its effect on smoker and non-smoker students based on the spirometer results.

Table 1. Differences of mean \pm standard deviation (SD) between group 1 (smokers) and group 2 (non-smokers) in the pre- and immediately post-work tests

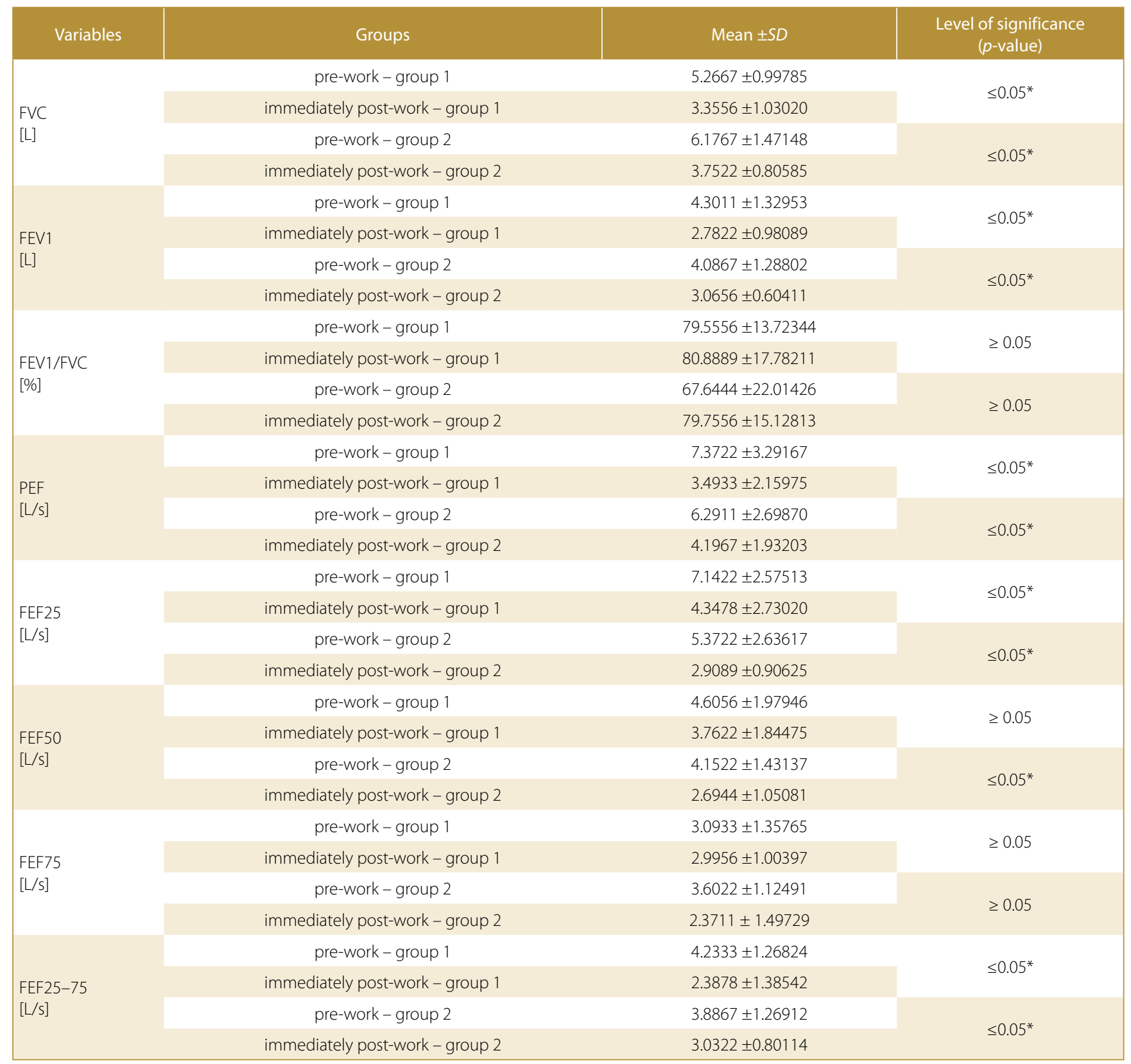

FVC - forced vital capacity; FEV1 - forced expiratory volume in 1 s; PEF - peak expiratory flow; FEF25, FEV50, FEV75 - forced expiratory flow at 25\%, 50\% and 75\%

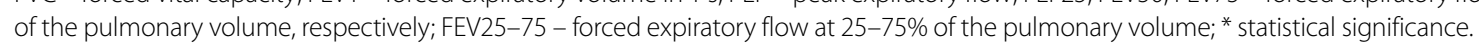


Table 2. Results of the analysis of variance (ANOVA)

\begin{tabular}{|c|c|c|}
\hline Parameters & Relation & $p$-value \\
\hline $\begin{array}{l}\text { FVC } \\
{[\mathrm{L}]}\end{array}$ & $\begin{array}{c}\text { group } 1 \text { and group } 2 \\
\text { pre- and immediately post-work tests }\end{array}$ & $\geq 0.05$ \\
\hline $\begin{array}{l}\text { FEV1 } \\
{[\mathrm{L}]}\end{array}$ & $\begin{array}{c}\text { group } 1 \text { and group } 2 \\
\text { pre- and immediately post-work tests }\end{array}$ & $\geq 0.05$ \\
\hline $\begin{array}{l}\text { FEV1/FVC } \\
{[\%]}\end{array}$ & $\begin{array}{c}\text { group } 1 \text { and group } 2 \\
\text { pre- and immediately post-work tests }\end{array}$ & $\geq 0.05$ \\
\hline $\begin{array}{l}\mathrm{PEF} \\
{[\mathrm{L} / \mathrm{S}]}\end{array}$ & $\begin{array}{c}\text { group } 1 \text { and group } 2 \\
\text { pre- and immediately post-work tests }\end{array}$ & $\geq 0.05$ \\
\hline $\begin{array}{l}\mathrm{FEF} 25 \\
{[\mathrm{~L} / \mathrm{S}]}\end{array}$ & $\begin{array}{c}\text { group } 1 \text { and group } 2 \\
\text { pre- and immediately post-work tests }\end{array}$ & $\geq 0.05$ \\
\hline $\begin{array}{l}\text { FEF50 } \\
{[\mathrm{L} / \mathrm{s}]}\end{array}$ & $\begin{array}{l}\text { group } 1 \text { and group } 2 \\
\text { pre- and immediately post-work tests }\end{array}$ & $\geq 0.05$ \\
\hline $\begin{array}{l}\text { FEF75 } \\
{[\mathrm{L} / \mathrm{S}]}\end{array}$ & $\begin{array}{c}\text { group } 1 \text { and group } 2 \\
\text { pre- and immediately post-work tests }\end{array}$ & $\geq 0.05$ \\
\hline $\begin{array}{l}\text { FEF25-75 } \\
{[\mathrm{L} / \mathrm{s}]}\end{array}$ & $\begin{array}{c}\text { group } 1 \text { and group } 2 \\
\text { pre- and immediately post-work tests }\end{array}$ & $\geq 0.05$ \\
\hline
\end{tabular}

The choice of smoker volunteers was motivated by their irritated respiratory airways due to chronic exposure to nicotine, which was supposed to render them highly susceptible to MMA vapor. ${ }^{21}$

The spirometer results revealed a significant reduction of FVC and FVC1 as we compared the pre- and post-work findings for smokers and non-smokers; this indicates restricted pulmonary function, with or without obstruction. This could be explained by the effect of MMA on the chemical receptors of respiratory epithelia, leading to the stimulation of the respiratory center, and thus causing bronchoconstriction. ${ }^{22}$ Our results coincide with those presented by Marez et al., who observed an obstructive effect of MMA vapor during inhalation, but related to the duration of exposure. ${ }^{23}$ Borak et al. also confirm that MMA is a lung-irritating substance and affects the airways causing obstruction and bronchial hyperactivity. ${ }^{24}$

Upon the comparison of the results between smokers and non-smokers, we found no statistically significant differences, which may be due to the small sample size or the number of cigarettes smoked per day. Apart from that, students were young and physically active males. This explanation is confirmed by Urrutia et al., who found that the level of pulmonary problems depended on the number of cigarettes smoked and age. ${ }^{13}$

Non-smokers showed respiratory reactivity in the postexposure results, especially at the level of FEV50 and FEV25, while smokers were found to have a restriction at the level of FEV 25 only. This could be explained by the thickening of lining epithelia and mucus secretion, which could interrupt the diffusion of MMA vapor across the small bronchioles of smokers, in addition to decreased endothelial responsiveness. Although no statistical significant difference was observed between the groups, the recorded results of non-smokers showed more pulmonary restriction. The reason for that may be the absorption of organic vapor through respiratory epithelia, causing a moderate restrictive response, as the vapor is non-polar, molecularly small-sized organic substance that easily passes to the lower respiratory tract, leading to a delayed effect when exposure is extensive. ${ }^{25}$ It requires future evaluation of the students near the end of their training course to provide enough information about that delayed response.

\section{Conclusions}

Although the sample size was small, the findings of the current study revealed that a moderate pulmonary restriction, with or without obstruction, was observed in both smokers and non-smokers exposed to acute MMA vapor, with more reactivity in non-smokers. No statistically significant differences in the results of the respiratory function tests were found between smokers and nonsmokers exposed to acute MMA vapor inhalation.

\section{ORCID iDs}

Malath Azeez Al-Saadi (i) https://orcid.org/0000-0001-6312-1115

Anas Al-Yasiry (1) https://orcid.org/0000-0001-7069-7868

Zainab Al-Jammali (1) https://orcid.org/0000-0002-1821-3659

Aoss Moez (1) https://orcid.org/0000-0002-3165-8628

\section{References}

1. Aalto-Korte K, Alanko K, Kuuliala O, Jolanki R. Methacrylate and acrylate allergy in dental personnel. Contact Dermatitis. 2007;57(5):324-330.

2. Pohanish RP. Sittig's Handbook of Toxic and Hazardous Chemicals and Carcinogens. Vol. 1. Norwich, NY: Noyes/William Andrews Publishing; 2002:1595.

3. Chan PC, Eustis SL, Huff JE, Haseman JK, Ragan H. Two-year inhalation carcinogenesis studies of methyl methacrylate in rats and mice: Inflammation and degeneration of nasal epithelium. Toxicology. 1988;52(3):237- 252.

4. Sasseville D. Acrylates in contact dermatitis. Dermatitis. 2012;23(1):6-16.

5. Blanchet LJ, Bowman MS, McReynolds HD. Effects of methyl methacrylate monomer vapors on respiration and circulation in unanesthetized rats. J Prosthet Dent. 1982;48(3):344-347.

6. Brüning T, Bartsch R, Bolt HM, et al. Sensory irritation as a basis for setting occupational exposure limits. Arch Toxicol. 2014;88(10):1855-1879.

7. Gautam R, Singh RD, Sharma VP, Siddhartha R, Chand P, Kumar R. Biocompatibility of polymethylmethacrylate resins used in dentistry. J Biomed Mater Res B Appl Biomater. 2012;100(B):1444-1450.

8. Lyapina M, Dencheva M, Krasteva A, Tzekova M, Kisselova-Yaneva A. Concomitant contact allergy to formaldehyde and methacrylic monomers in students of dental medicine and dental patients. Int J Occup Med Environ Health. 2014;27(5):797-807.

9. Rashid $\mathrm{H}$, Sheikh Z, Vohra F. Allergic effects of the residual monomer used in denture base acrylic resins. Eur J Dent. 2015;9(4):614-619.

10. Walther UI, Walther SC, Liebl B, et al. Cytotoxicity of ingredients of various dental materials and related compounds in L2- and A549 cells. J Biomed Mater Res. 2002;63(5):643-649.

11. Sokmen S, Oktemer M. Histopathological examinations of rat lungs that exposed to low concentration of methyl methacrylate monomer vapor. J Hacettepe Fac Dent. 1988;12:1-4.

12. Ferrer $\mathrm{E}$, Peinado VI, Díez $\mathrm{M}$, et al. Effects of cigarette smoke on endothelial function of pulmonary arteries in the guinea pig. Respir Res. 2009;10:76.

13. Urrutia I, Capelastegui A, Quintana JM, Muñiozguren N, Basagana X, Sunyer J; Spanish Group of the European Community Respiratory Health Survey (ECRHS-I). Smoking habit, respiratory symptoms and lung function in young adults. Eur J Public Health. 2005;15(2):160-165. 
14. Sin DD, Wu L, Man SF. The relationship between reduced lung function and cardiovascular mortality: A population-based study and a systematic review of the literature. Chest. 2005;127(6):1952-1959.

15. Mannino DM, Holguin F, Pavlin BI, Ferdinands JM. Risk factors for prevalence of and mortality related to restriction on spirometry: Findings from the First National Health and Nutrition Examination Survey and follow-up. Int J Tuberc Lung Dis. 2005;9(6):613-621.

16. Al-Yasiry A, Al-Jammali ZM, Almuthaffer A, Moez A. Effect of monomer inhalation on the lung function volume of dentistry female students by using the spirometer. Med J Babylon. 2017;14(2):300-308.

17. Pellegrino R, Viegi $G$, Brusasco V, et al. Interpretative strategies for lung function tests. Eur Respir J. 2005;26(5):948-968.

18. Gosavi SS, Gosavi SY, Alla RK. Local and systemic effects of unpolymerised monomers. Dent Res J (Isfahan). 2010;7(2):82-87.

19. Lyapina M, Dencheva M, Krasteva A, et al. Health risk assessment in exposure to methacrylic monomers in dental practice. J Sci Res Rep. 2014;3(22):2848-2863.

20. Hankinson JL, Odencrantz JR, Fedan KB. Spirometric reference values from a sample of the general U.S. population. Am J Respir Crit Care Med. 1999;159(1):179-187.

21. Miller K, Chang A. Acute inhalation injury. Emerg Med Clin North Am. 2003;21(2):533-535.

22. Kenfield SA, Wei EK, Rosner BA, Glynn RJ, Stampfer MJ, Colditz GA. Burden of smoking on cause-specific mortality: Application to the Nurses' Health Study. Tob Control. 2010;19(3):248-254.

23. Marez T, Edmé JL, Bulenguez C, Shirali P, Haguenoer JM. Bronchial symptoms and respiratory function in workers exposed to methylmethacrylate. Br J Ind Med. 1993;50(10):894-897.

24. Borak J, Fields C, Andrews LS, Pemberton MA. Methyl methacrylate and respiratory sensitization: A critical review. Crit Rev Toxicol. 2011;41(3):230-268.

25. Gorguner M, Akgun M. Acute inhalation injury. Eurasian J Med. 2010;42(1):28-35. 